forestry school should be established in Saskatchewan was not supported by the Commission on the grounds that facilities for technical training in Canada were already adequate. On the other hand, the work of the forest ranger school established by the Government was heartily commended.

On the question of administrative control of the publicly-owned forests, the Commissioners divided, the majority recommending that control should continue to be exercised by the Minister of Natural Resources and Industrial Development. The minority recommended that the forests should be ad. ministered by an independent commission, to be appointed by the Government for a fixed period of years which should be responsible directly to the Leg. islature.

Public interest in the forest resources leaves a great deal to be desired, chiefly because most of the people live in the southern part of the province and seldom if ever see a forest. The urgency of forestry problems justifies a vigorous campaign of public education, which should receive all possible support from the Government.

The Secretary,

\title{
CORRESPONDENCE
}

Canadian Society of Forest Engineers,

10 Manor Road West,

Toronto, Ontario, Canada.

Dear Sir,-

Seventh Pacific Science Congress During February 1949

Enclosed please find circular literature concerning the above, which will be, it is hoped, self-explanatory.

My Institute has been requested by the General Committee of Congress to ensure that no interested professional forestry organization is overlooked and left unadvised of the Congress.

If any of your Society's members can participate or send papers for presentation, every possible assistance will be given them locally by the N.Z. Institute of Foresters and they can rest assured of a cordial welcome from their fellow foresters here.

Yours faithfully,

(Signed C. W. Smith)

Convenor, Congress Committee

New Zealand Institute of Foresters, Ostober $15,1948$.

FOREST PRODUCTS SPECIALISTS MEET IN OTTAWA

Timber mechanics specialists from seven countries recently completed a successful two weeks of meetings in Ottawa. This Conference was the outcome of a decision taken at the British Empire Forestry Conference in 1947 when a standing committee on forest products research was organized. In arranging for this Timber Mechanics Conference to be held in Ottawa, it was decided to broaden its scope by inviting representatives from the United States Forest Products Laboratory at Madison, Wisconsin. The Conference in Ottawa was under the chairmanship of T. A. McElhanney, 
Superintendent of the Forest Products Laboratory, Ottawa. Delegates to the Conference were: J. Latham of England; K. L. Cooper, Australia; J. S. Reid, New Zealand; M. H. Scott, Union of South Africa; A. V. Thomas, Malaya; W. E. Wakefield and J. B. Alexander, Canada. L. J. Markwardt, Assistant Director of the Forest Products Laboratory, Madison, headed the United States delegation comprising R. P. A. Johnson, J. T. Drow, J. A. Liska, and W. G. Youngquist.

\section{CLARENCE COOPER RESIGNS}

Late in January, 1944, the Incoming Executive of the Society for that year sat in a room in the Mount Royal Hotel, Montreal, and wrestled with the problem that periodicaliy recurs in our organization-and probably in most others like it-that of securing a competent and hard-working individual to serve as Secretary-Treasurer. After six years of yeoman service-during which time he played no small part in building up enthusiasm, our numerical strength, and our finances-Alan Fenwick had announced that he would have to relinquish the office. The problem was to find a successor!

Then, as now, the Executive was faced with the desirability of securing someone resident in Toronto, to obviate the necessity of locating new office accommodation and packing the documents and impedimenta that had accumulated in the thirtysix years the Society had been in operation.

It was then, as one of his last contributions to duty, that Alan Fenwick came up with the name of Clarence Cooper. The appointment presented difficulties for, although Clarence was an honest-to-goodness graduate of the Faculty of Forestry, Toronto, he had subsequently strayed into the legal profession and, hence, could not be appointed under a strict interpretation of the Society's By-laws. Desperate straits requiring desperate measures, the harassed Executive approved Clarence Cooper's application for Affliate Membership and appointed him as Acting Secretary-Treasurer.

The end has more than justified the means. For the intervening four years, Clarence has served the interests of the Society ably and conscientiously. Where Alan Fenwick had surmounted problems of dormant interest and meagre finances, Clarence Cooper has coped with intensified activity and a rapidly increasing membership. Moreover, in addition to carrying on the 'normal occasions' of his offce he has generously and willingly given of his specialized knowledge and experience in legal problems.

At the recent Annual Meeting, Clarence tendered his resignation, his health necessitating a move from Toronto. The Executive with the greatest regret perforce had to accept. Members of the Executive and the Society at large who have worked with him will regret his departure and wish him good fortune in his new location and endeavours. As a final contribution, Clarence suggested the name of the member who has since consented to assume the duties and responsibilities of the office-Professor David V. Love, Faculty of Forestry, University of Toronto, who will carry on our work at the old stand-10 Manor Road West, Toronto.

ERIC Druce 